\title{
The role of cell-surface-bound phosphatases in species competition within natural phytoplankton assemblage: an in situ experiment
}

\author{
Alena ŠTROJSOVÁ ${ }^{1,2)}$, Jiř́ NEDOMA ${ }^{1)}$, Martina ŠTROJSOVÁ ${ }^{1,2)}$, Xiuyun $\mathrm{CAO}^{3)}$ and Jaroslav VRBA ${ }^{1,2) *}$ \\ ${ }^{1)}$ University of South Bohemia, Faculty of Science, Branišovská 31, CZ-370 05 České Budějovice, Czech Republic \\ ${ }^{2)}$ Biology Centre AS CR, Institute of Hydrobiology, Na Sádkách 7, CZ-370 05 České Budějovice, Czech Republic \\ ${ }^{3)}$ Institute of Hydrobiology, Chinese Academy of Sciences, Wuhan 430072, PR China \\ * e-mail corresponding author: vrba@hbu.cas.cz
}

\begin{abstract}
Despite it is widely acknowledged that the ability to hydrolyze dissolved organic matter using extracellular phosphatases is diverse in freshwater phytoplankton, the competition within single species related to presence and quantity of cell-surface-bound phosphatases has not been examined in natural conditions yet. Here, we studied phytoplankton species competition in a freshwater reservoir during an in situ experiment. A natural plankton community, with the exclusion of large zooplankton, was enclosed in permeable dialysis bags inside two large containers of different bioavailable phosphate concentrations. Phytoplankton species biomass and the abundance of bacteria were determined in purpose to compare the development of enclosed microbial communities. Total and cell-surface-bound phosphatase activities in the phytoplankton were investigated using the Fluorescently Labelled Enzyme Activity (FLEA) technique that allows for direct microscopic detection of phosphatase-positive cells and, with image cytometry, enables quantification of phosphatase hydrolytic capacity. Production of extracellular phosphatases was not completely inhibited or stopped in the phosphate-enriched environment, phytoplankton cells only showed the activity less often. Under the phosphate-nonenriched conditions, the production of phosphatases was enhanced, but active species did not proliferate amongst phytoplankton assemblage. Further, specific growth rates of the phosphatase-positive species in the non-enriched environment were lower than the same phosphatase-positive species in phosphate-enriched environment. Interestingly, the phosphatase-positive cells of Ankyra ancora increased their size in both treatments equally, although the population in phosphate-enriched environment grew much faster and the cell-specific phosphatase activity was lower. We hypothesize that brand new daughter cells had sufficient phosphorus reserves and therefore did not employ extracellular phosphatases until they matured and needed extra bioavailable phosphorus to support their metabolism before cell division. Based on presented in situ experiment, we propose that the ability to hydrolyze organic polymers and particles with cell-surface-bound phosphatases is advantageous for longer persistence of given population in a phosphate-scarce environment; although phosphatase-positive species cannot dominate the reservoir phytoplankton solely because of specific phosphorus-scavenging strategy.
\end{abstract}

Key words: competition, ectoenzyme, ELF97 phosphate, image cytometry, species-specific activity

\section{INTRODUCTION}

Species diversity in phytoplankton assemblages have been intensively studied for decades because phytoplankton composition influences the aquatic food web as well as the water quality in terms of, e.g., algal blooms. The availability of nutrients is considered to be a crucial factor regulating species diversity. When the intracellular storage of nutrients is exhausted, growth rates are regulated by the external supply rate of the limiting nutrient (for review, see Reynolds 1997). The most often growth-limiting factor in freshwaters is phosphorus. Its bioavailable form, orthophosphate $\left(\mathrm{P}_{\mathrm{i}}\right)$, can be depleted rapidly in freshwaters (Hecky \& Kilham 1988). Many algal and cyanobacterial species synthesise extracellular phosphatases when they lack $\mathrm{P}_{\mathrm{i}}$, because it allows access to organically bound P-compounds (Siuda \& Chróst 1987; Jansson et al. 1988). Moreover, Chróst (1991) suggested that cell-associated extracellular enzymes might allow the producer to dominate nutrientdepleted ecosystem through its nutritional advantage.
The occurrence of extracellular phosphatase activity could diagnose starvation of phytoplankton (Kuenzler \& Perras 1965; Dyhrman et al. 2002); cells that produce phosphatases are most probably without polyphosphate storage and lack $P_{i}$. Phosphatase activity can be directly visualised with a fluorogenic substrate, ELF $^{\mathbb{B}} 97$ phosphate (ELFP, Huang et al. 1992). A phosphate group is hydrolysed from the water-soluble ELFP molecule in the presence of either alkaline or acid phosphatases (Štrojsová \& Vrba 2006). The resulting fluorescent product of the hydrolysis is ELF alcohol (ELFA), which precipitates at or near the site of enzyme activity and thus can distinguish the cells or populations within phytoplankton assemblages that are able to scavenge P. The Fluorescently Labelled Enzyme Activity (FLEA) assay (in earlier articles imprecisely called as ELF technique, as well) has been used to study enzymatic activities of marine phytoplankton and algal cultures (Gonzáles-Gil et al. 1998; Dyhrman \& Palenik 1999; Lomas et al. 2004, Dyhrman \& Ruttenberg 2006; Štrojsová \& Dyhrman 2008), freshwater phytoplankton 


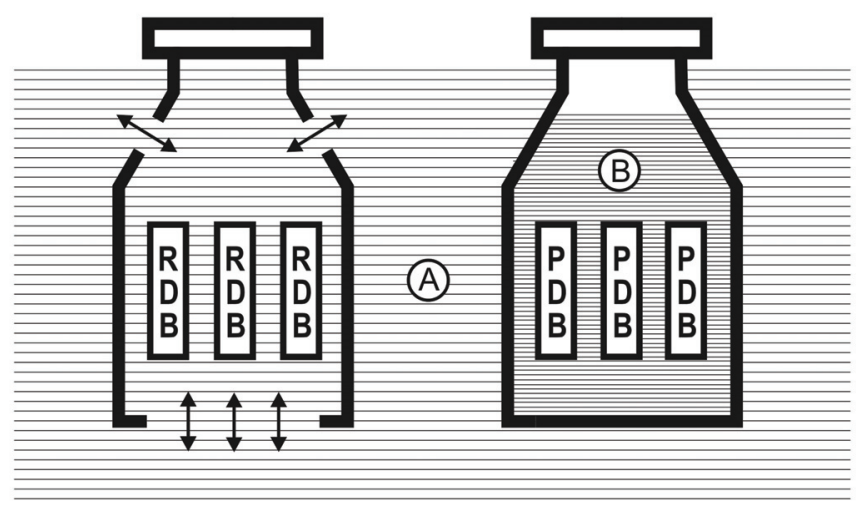

(A) Reservoir water

(B) $\mathrm{Pi}$ enriched water

Fig. 1. Diagram of the experimental design. Left: open polyethylene container submerged in the reservoir water with three dialysis bags assigned as RDB. Right: container with reservoir water enriched with $\mathrm{P}_{\mathrm{i}}$ and three dialysis bags assigned as PDB. RDB and PDB contained filtered reservoir water without large zooplankton.

(Rengefors et al. 2003; Štrojsová et al. 2003; Dignum et al. 2004; Cao et al. 2005; Štrojsová \& Vrba 2008) and planktonic rotifers (Štrojsová \& Vrba 2005, 2007). ELFA fluorescence of chosen objects can be quantified using epifluorescence microscopy and image analysis (Nedoma et al. 2003; Štrojsová et al. 2005).

Phosphorus enrichment bioassays have a long history in both fresh and marine waters (e.g., Wetzel 1981; Gonzáles 2000; Ojala et al. 2003; Rengefors et al. 2003). Orthophosphate is added and planktonic growth rates and biomass are compared relative to an unenriched control. The change in $\mathrm{P}_{\mathrm{i}}$ concentration is typically accompanied by changes in phosphatase activity at the species level (Štrojsová et al. 2005). In most cases, enrichment results in increased biomass as well as a change in species composition (e.g., Arvola et al. 1996; Cottingham et al. 1998; Kobayashi \& Church 2003).

In this in situ enclosure experiment, we examined effects of $P_{i}$ enrichment on phytoplankton extracellular phosphatases, including bacteria, as important components of microbial community in the Rímov Reservoir. We conducted the in situ experiment in late June, when P-limiting conditions usually develop. Alkaline phosphatase activity was detected and quantified using the FLEA assay and image cytometry. Two main objectives were addressed: (i) how does enrichment affect both plankton biomass dynamics and extracellular phosphatase activities at the species level? and (ii) are species that produce cell-associated phosphatases in advantage to the other, non-active species in natural phytoplankton assemblage, e.g., reaching extra $\mathrm{P}_{\mathrm{i}}$ from dissolved organic phosphorus (DOP) compounds, could these species increase their specific growth rates?

\section{MATERIAL AND METHODS}

\subsection{Study site and experimental design}

The eutrophic Rímov Reservoir is situated on the Malše River (Czech Republic; 48 $83^{\prime} \mathrm{N}$; 14 ${ }^{\circ} 46^{\prime} \mathrm{E}$ ). The main reservoir characteristics are: area $2.06 \mathrm{~km}^{2}$, vol- ume $34.5 \times 10^{6} \mathrm{~m}^{3}$, length $13.5 \mathrm{~km}$, max./mean depth 43/16.5 m, mean retention time 100 days (Vrba et al. 1993). P-limiting conditions develop regularly during summer stratification in the euphotic zone.

The enclosure experiment was conducted on 18-25 June 2004 after the clear-water phase, which was characterised by the dominance of cryptomonad populations (Cryptomonas reflexa, C. erosa, and Rhodomonas minuta). Design of the experiment is presented in a diagram (Fig. 1). Water was sampled with a Friedinger sampler from a depth of $0.5 \mathrm{~m}$ at a sampling site located in the dam area. It was then filtered through a sieve (200 $\mu \mathrm{m})$ to exclude large zooplankton and collected in a 50 $\mathrm{L}$ container. Three dialysis bags (diameter $75 \mathrm{~mm}, 1216$ $\mathrm{kDa}$, Poly Labo, France), were filled with $2.5 \mathrm{~L}$ of water from the container and placed vertically into a transparent polyethylene container $(\sim 80 \%$ of ambient light intensity, $50 \mathrm{~L}$ ) that was supposed to simulate the reservoir (initial ambient concentration $7.7 \mu \mathrm{g} \mathrm{SRP} \mathrm{L}{ }^{-1}$ ) and was filled with unfiltered epilimnetic water amended by $\mathrm{K}_{2} \mathrm{HPO}_{4}$ (final concentration $62 \mu \mathrm{g} \mathrm{P} \mathrm{L}^{-1}$ ). These P-enriched dialysis bags were designated as PDB. Three other dialysis bags (designated as RDB, no nutrient addition) were placed vertically in a bottomless control container with four triangular holes $(\sim 10 \mathrm{~cm})$ on the sides to enable continuous reservoir-water exchange.

From each dialysis bag, samples were taken for plankton, chemical, and enzyme analyses on days $0,3,5$ and 7 between 8.00 to 9.00 a.m. and transported immediately to the laboratory. All enzyme assays were processed within the next 3 hours. Water samples $(\sim 300 \mathrm{~mL})$ were taken for particulate organic carbon, total $\mathrm{P}$ (neither analysed at day 5), soluble reactive P (SRP), and chlorophyll- $a$ analyses. In addition, both containers were sampled and analysed for SRP and chlorophyll- $a$. Phytoplankton and rotifers were determined in the same samples $(20 \mathrm{~mL})$ preserved with Lugol's solution; other samples $(20 \mathrm{~mL})$ for bacteria determination were fixed with formaldehyde ( $2 \%$ final concentration). 


\subsection{Phosphatase assays}

Three assays were used to determine phosphatase activity in the dialysis bags: (i) the MUF assay for measuring total phosphatase activity $\left(\mathrm{PA}_{\mathrm{T}}\right)$; (ii) the FLEA assay for phosphatase activity detected on filters $\left(\mathrm{PA}_{\mathrm{F}}\right)$; and (iii) the FLEA assay modified for measuring of cell-surface-bound phosphatase activity of single cells of phytoplankton (here Ankyra ancora, $\mathrm{PA}_{\mathrm{A}}$ ).

Total phosphatase activity $\left(\mathrm{PA}_{\mathrm{T}}\right)$ was assayed with the common spectrofluorimetric method (Hoppe 1983) using 4-methyllumbelliferyl phosphate (MUFP, Glycosynth, UK). Duplicates of water samples were buffered with Tris/ $\mathrm{HCl}$ buffer ( $\mathrm{pH} 7.5 ; 10 \mathrm{mmol} \mathrm{L}^{-1}$ final concentration), supplemented with MUFP (100 $\mu \mathrm{mol} \mathrm{\textrm {L } ^ { - 1 }}$ final concentration) and incubated for $2 \mathrm{~h}$ at $20^{\circ} \mathrm{C}$. The incubation was terminated by $\mathrm{HgCl}_{2}$ addition ( $4 \mathrm{mmol}$ $\mathrm{L}^{-1}$ final concentration). Parallel duplicates supplemented only with $\mathrm{HgCl}_{2}$ were always incubated as blanks (Christian \& Karl 1995). Prior to fluorescence reading, an alkaline solution $\left(40 \mathrm{mmol} \mathrm{L}^{-1}\right.$ of $\mathrm{NaOH}$ with $8 \mathrm{mmol} \mathrm{L}^{-1}$ of EDTA final concentrations, Vrba et al. 1993) was added. Fluorescence was measured using a spectrophotometer, with a fluorometric device (excitation at $365 \mathrm{~nm}$ and emission $465 \mathrm{~nm}$ ) and corrected for the blank.

The protocol by Nedoma et al. (2003) for FLEA was followed for measuring both $\mathrm{PA}_{\mathrm{F}}$ and $\mathrm{PA}_{\mathrm{A}}$. Water samples $(4 \mathrm{~mL})$ were incubated with $\mathrm{ELF}^{\circledR} 97$ phosphate (ELFP, Invitrogen - Molecular Probes; $20 \mu \mathrm{mol} \mathrm{L} \mathrm{L}^{-1}$ final concentration) at $20{ }^{\circ} \mathrm{C}$. Samples were buffered with Tris/ $\mathrm{HCl}$ buffer $\left(\mathrm{pH} 7.5 ; 10 \mathrm{mmol} \mathrm{L}^{-1}\right.$ final concentration) to ensure ELF alcohol (ELFA) precipitation. The incubation started within 1 hour after sampling. After a $2 \mathrm{~h}$ incubation, the samples were fixed with $\mathrm{HgCl}_{2}$ (4 mmol L $\mathrm{L}^{-1}$ final concentration) to prevent destruction of fragile flagellates and filtered over mild vacuum $(<20 \mathrm{kPa})$ through a membrane filter $(0.8 \mu \mathrm{m}$ pore size). Filters with retained plankton were inspected for the presence of ELFA precipitates with an epifluorescence microscope (Olympus AX-70, Japan) with the UV-excitation filter set (excitation / emission: 360-370 $\mathrm{nm} />420 \mathrm{~nm}$ ). Both green ELFA fluorescence and red autofluorescence of chlorophyll- $a$ were visible using this filter set.

A set of 40 images with ELFA fluorescence was taken from randomly selected areas $(470 \times 290 \mu \mathrm{m}$ to quantify the phosphatase activity on a filter $\left(\mathrm{PA}_{\mathrm{F}}\right)$ using the ELFA-specific filter set (excitation / emission: 360$370 \mathrm{~nm} / 520-540 \mathrm{~nm}$ ). To quantify phosphatase activity of Ankyra ancora $\left(\mathrm{PA}_{\mathrm{A}}\right)$, a set of images was taken to obtain typically 25 or more cells. The Lucia G/F 4.8 image analysis software (Laboratory Imaging, Czech Republic) was used for image processing and fluorescence quantification (more detailed description in Nedoma et al. 2003). Relative ELFA fluorescence in fluorescence units (FU) on a chosen area was calculated from the mean grey of the area, the mean grey of the background, camera sensitivity, intensity of excitation light, and the objective-specific correction factor. ELFA (in fmol) was determined by multiplying the relative ELFA fluorescence by a conversion factor of $2.4 \mathrm{fmol}$ $\mathrm{FU}^{-1}$, determined by comparing the fluorescence of the same samples measured by image cytometry and in a spectrofluorimeter (Nedoma et al. 2003). The $\mathrm{PA}_{\mathrm{A}}$ of Ankyra ancora was normalised per unit of plane projection area of each active cell measured.

\subsection{Other methods}

Soluble reactive phosphorus (SRP) was determined spectrophotometrically by the molybdate method (Murphy \& Riley 1962). Total and dissolved phosphorus (TP and DP) were determined by perchloric acid digestion and the molybdate method according to Kopáček \& Hejzlar (1993). Particulate phosphorus (PP) was determined as the difference between TP and DP and dissolved organic phosphorus (DOP) as the difference between DP and SRP. Particulate organic carbon (POC) was analysed by combustion of the glass-fibre filter with the retained particulate organic matter in a TOC 5000A analyser (Shimadzu, Kyoto, Japan). Molar $\mathrm{C}: \mathrm{P}$ ratios were calculated from PP and POC. Concentration of chlorophyll- $a$ (chl- $a$ ) was determined fluorimetrically after acetone extraction using the whole-water technique (Vyhnálek 1994). Unfiltered phytoplankton samples preserved with acid Lugol's solution were quantified in Utermöhl's sedimentation chambers on an inverted microscope after at least oneday sedimentation. Species-specific cell volumes, including flagellates (3-20 $\mu \mathrm{m}$ of cell diameter), were calculated from size measurements of living cells using geometric volume approximation. A conversion factor of $1 \mathrm{mg} \mathrm{mm}^{-3}$ of algal fresh mass was assumed. Specific growth rates of selected phytoplankton species were determined as the slope of the linear regression of the natural logarithm of cell density versus time. Bacteria were counted after DAPI staining using epifluorescence microscopy (Porter \& Feig 1980). Bacterial biovolumes were measured with image analysis (Lucia G/F 4.8, Psenner 1993); cellular carbon content was calculated according to Norland (1993).

An unpaired $t$-Test was performed to compare triplicate means of $\mathrm{PA}_{\mathrm{F}}$ and $\mathrm{PA}_{\mathrm{A}}$ and phytoplankton biomasses determined from $\mathrm{PDB}$ and RDB. The relationships between $\mathrm{PA}_{\mathrm{F}}$ or $\mathrm{PA}_{\mathrm{A}}$ and $\mathrm{TP}, \mathrm{DOP}$ or SRP were tested with a nonparametric Spearman rank correlation. Qualitative differences between the numbers of phosphatase-positive and non-positive taxa were tested using contingency tables and a $\chi^{2}$ test. The above analyses were performed using Prism 4.0 (GraphPad, CA).

\section{RESULTS}

The proportions (abundance) of phytoplankton groups changed similarly in the non-enriched RDB and enriched PDB treatments during the first three days of 

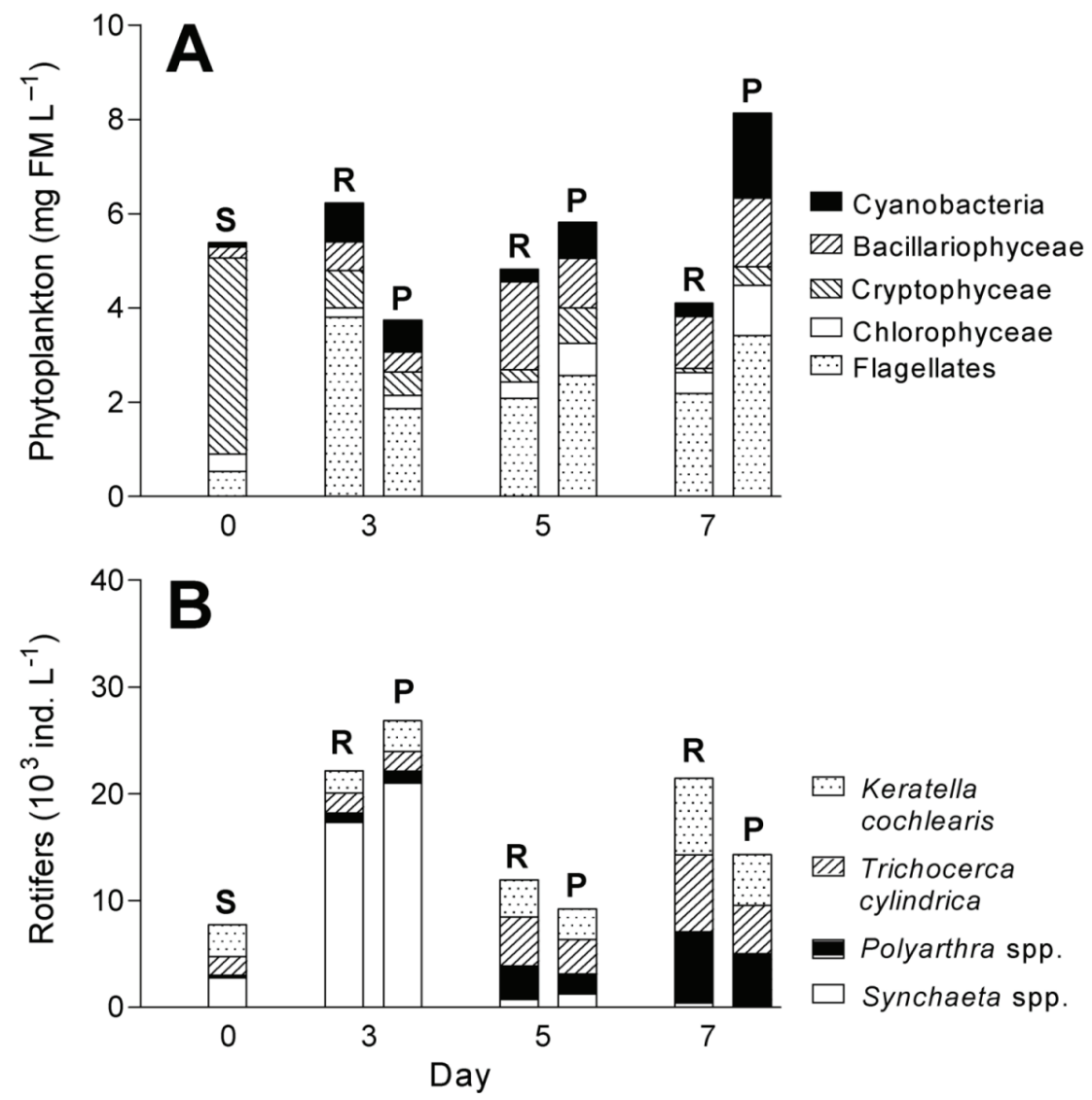

Fig. 2. Development of phytoplankton and rotifers during the in situ experiment: A: Phytoplankton biomass (as fresh mass, FM); and B: The most abundant rotifers. Bars represent means of triplicates in RDB (R) and PDB (P); S is the initial situation in the reservoir water.

the experiment. Initially, phytoplankton were dominated by cryptomonads, which were replaced by other populations, namely cyanobacteria, diatoms and flagellates, within three days (Fig. 2A). Overall, phytoplankton biomass increased more in the enriched PDB than in RDB by the day 7 ( $t$-Test, $P=0.041)$. Moreover, fewer phytoplankton species were phosphatase-positive (Tab. 1) and specific growth rates of particular species were higher in PDB by the end of the in situ experiment (Tab. 2).

Initial DOP and SRP concentrations in the dialysis bags were $19.8 \mu \mathrm{g} \mathrm{L}^{-1}$ and $7.5 \mu \mathrm{g} \mathrm{L}^{-1}$, respectively (Fig. $3 \mathrm{~A})$ whereas the ambient SRP concentration in the Pcontainer reflected the $\mathrm{P}$ addition. The concentration of SRP in the P-container decreased after 5 days to $6.25 \mu \mathrm{g}$ $\mathrm{L}^{-1}$ and after 7 days reached $2.9 \mu \mathrm{g} \mathrm{L}^{-1}$, a similar value to that in the R-container $\left(2.2 \mu \mathrm{g} \mathrm{L}^{-1}\right.$; Fig. $\left.3 \mathrm{~A}\right)$. The initial addition of $\mathrm{P}_{\mathrm{i}}$ did not change measurably SRP levels in the PDB; SRP even declined $\left(2.6 \mu \mathrm{g} \mathrm{L}^{-1}\right)$ similarly as in the non-enriched RDB $\left(2.6 \mu \mathrm{g} \mathrm{L}^{-1}\right)$ by day 3 . On the other hand, TP increased in both treatments, but more in the PDB (55.7 $\mu \mathrm{g} \mathrm{L}^{-1}$ and $79.2 \mu \mathrm{g} \mathrm{L}^{-1}$; Fig. 3A). Initially, the $\mathrm{C}: \mathrm{P}$ ratio was 144 and decreased by the end of the experiment in both RDB and PDB (C:P $=132$ and 107 , respectively).

Initial chl- $a$ concentration in the dialysis bags was $36.9 \mu \mathrm{g} \mathrm{L}^{-1}$, which then decreased in all variants by day
3 (9-12 $\mu \mathrm{g} \mathrm{L}^{-1}$, Fig. 3B). After that, the decline continued in the R-container, which equalled that of open water, being only $5.8 \mu \mathrm{g} \mathrm{L}^{-1}$ at day 7 . There was an increase in chl- $a$ by day $7\left(17.5 \mu \mathrm{g} \mathrm{L}^{-1}\right)$ in the RDB. Chl- $a$ increased in the P-container four times since day $3\left(47 \mu \mathrm{g} \mathrm{L}^{-1}\right)$, while its concentration increased in the PDB by day 5 and then decreased to the same level as in the RDB (Fig. 3B).

\subsection{Plankton composition and development}

Species composition of the phytoplankton is given in table 1. Cryptophyceae (Cryptomonas erosa and $C$. reflexa) dominated the phytoplankton at the beginning of the enclosure experiment ( $>85 \%$ of total biomass), while Cyanobacteria, Bacillariophyceae, Chlorophyceae and flagellates were rather negligible (altogether $<15 \%$; Fig. 2A). Cryptomonads decreased rapidly in the dialysis bags; they declined to $<5 \%$ of total biomass in RDB by day 7 (from the initial $4.2 \mathrm{mg} \mathrm{L}^{-1}$ to $0.08 \mathrm{mg} \mathrm{L}^{-1}$; Fig. 2A). Flagellate biomass increased both in the RDB and PDB samples (from the initial $0.54 \mathrm{mg} \mathrm{L}^{-1}$ to, respectively, $2.2 \mathrm{mg} \mathrm{L}^{-1}$ and $3.4 \mathrm{mg} \mathrm{L}^{-1}$ ); maximum of flagellates $\left(3.8 \mathrm{mg} \mathrm{L}^{-1}\right.$ ) occurred in RDB on day 3 followed by a decrease (Fig. 2A). 
Tab. 1. Summary of phytoplankton species/genera present in the Rímov Reservoir (Start), and in non-enriched (RDB) and enriched (PDB) dialysis bags, and inspected for ELFA labelling. Symbols: (x) several cells of the population ELFA-labelled, (xx) $>10 \%$ of the population ELFA-labelled, (o) present but not labelled.

\begin{tabular}{|c|c|c|c|}
\hline & Start & RDB & PDB \\
\hline \multicolumn{4}{|l|}{ Cyanobacteria } \\
\hline Anabaena planctonica Brunnth. & $\mathrm{x}$ & $\mathrm{x}$ & $\mathrm{x}$ \\
\hline Merismopedia sp. & o & $\mathrm{o}$ & o \\
\hline Planktothrix agardhii (Gom.) Anagn. et Kom. & o & o & o \\
\hline Pseudanabaena limnetica (Lemm.) Kom. & o & o & o \\
\hline Snowella litoralis Häyrén (Kom. et Hind.) & o & $\mathrm{x}$ & o \\
\hline Woronichinia naegeliana (Unger) Elenk. & o & o & o \\
\hline \multicolumn{4}{|l|}{ Chrysophyceae } \\
\hline Synura sp. & o & o & o \\
\hline \multicolumn{4}{|l|}{ Dinophyceae } \\
\hline Amphidinium sp. & o & o & o \\
\hline Gymnodinium uberrimum (Allman) Kofoid et Swezy & o & $\mathrm{x}$ & o \\
\hline \multicolumn{4}{|l|}{ Bacillariophyceae } \\
\hline Asterionella formosa Hass. & $\mathrm{o}$ & $\mathrm{x}$ & $\mathrm{o}$ \\
\hline Aulacoseira italica (Ehrenb.) Simonsen & o & $\mathrm{x}$ & o \\
\hline Cyclotella pseudostelligera Hust. & o & o & o \\
\hline Fragilaria crotonensis Kitt. & o & $\mathrm{x}$ & $\mathrm{o}$ \\
\hline Nitzschia acicularis W. Smith & o & o & o \\
\hline Stephanodiscus hantzschii Grun. & o & o & o \\
\hline \multicolumn{4}{|l|}{ Cryptophyceae } \\
\hline Cryptomonas erosa Ehrenb. & $\mathrm{o}$ & $\mathrm{o}$ & o \\
\hline Cryptomonas reflexa Skuja & o & o & o \\
\hline Rhodomonas minuta Skuja & $\mathrm{o}$ & o & o \\
\hline \multicolumn{4}{|l|}{ Chlorophyceae } \\
\hline Ankyra ancora (G.M. Smith) Fott & $\mathrm{xx}$ & $\mathrm{xx}$ & $\mathrm{xx}$ \\
\hline Crucigeniella apiculata (Lemm.) Kom. & o & $\mathrm{x}$ & $\mathrm{x}$ \\
\hline Dictyosphaerium sp. & o & $\mathrm{x}$ & o \\
\hline Elakatothrix genevensis (Reverd.) Hind. & o & o & o \\
\hline Eudorina elegans Ehrenb. & $\mathrm{x}$ & $\mathrm{x}$ & $\mathrm{o}$ \\
\hline Gonium sociale Warm. & o & $\mathrm{x}$ & $\mathrm{x}$ \\
\hline Chlamydomonas spp. & o & o & o \\
\hline Chlorogonium sp. & o & $\mathrm{o}$ & o \\
\hline Micractinium pusillum Fres. & $\mathrm{x}$ & $\mathrm{x}$ & o \\
\hline Monoraphidium contortum (Thur.) Kom.-Legn. & o & o & o \\
\hline Monoraphidium minutum (Näg.) Kom.-Legn. & o & o & o \\
\hline Oocystis parva W. et G.S. West & o & $\mathrm{x}$ & $\mathrm{x}$ \\
\hline Pandorina morum (O.F. Müller) Bory & o & $\mathrm{x}$ & $\mathrm{x}$ \\
\hline Pediastrum boryanum (Turp.) Menegh. & o & $\mathrm{x}$ & $\mathrm{x}$ \\
\hline Pediastrum duplex Meyen & $\mathrm{x}$ & o & $\mathrm{x}$ \\
\hline Pediastrum tetras (Ehrenb.) Ralfs & o & o & o \\
\hline Planktosphaeria gelatinosa G.M. Smith & o & $\mathrm{x}$ & $\mathrm{x}$ \\
\hline Scenedesmus sp. & $\mathrm{x}$ & $\mathrm{x}$ & $\mathrm{x}$ \\
\hline Tetraedron incus (Teil.) G.M. Smith & o & $\mathrm{o}$ & $\mathrm{o}$ \\
\hline Tetrastrum $\mathrm{sp}$ & o & $\mathrm{o}$ & $\mathrm{x}$ \\
\hline Total No. of ELFA-positive taxa & 6 & 17 & 11 \\
\hline
\end{tabular}

Tab. 2. Mean species-specific growth rates for the phytoplankton species in both non-enriched (RDB) and enriched (PDB) dialysis bags; \pm standard error. The PDB:RDB ratio implies the difference between the treatments. Median of specific growth rates for all the species in R-dialysis bags was 0.11 day $^{-1}$ and 0.32 day $^{-1}$ for the same species in P-dialysis bags.

\begin{tabular}{|c|c|c|c|c|c|}
\hline & $\operatorname{RDB}\left(\right.$ day $\left.^{-1}\right)$ & & $\operatorname{PDB}\left(\right.$ day $\left.^{-1}\right)$ & & PDB:RDB \\
\hline Anabaena planctonica & $0.11 \pm 0.19$ & + & $0.39 \pm 0.08$ & + & 3.5 \\
\hline Asterionella formosa & $0.22 \pm 0.06$ & + & $0.31 \pm 0.06$ & - & 1.4 \\
\hline Aulacoseira italica & $0.09 \pm 0.09$ & + & $0.17 \pm 0.21$ & - & 1.9 \\
\hline Nitzschia acicularis & $0.40 \pm 0.08$ & - & $0.47 \pm 0.21$ & - & 1.2 \\
\hline Ankyra ancora & $0.11 \pm 0.06$ & + & $0.36 \pm 0.16$ & + & 3.3 \\
\hline Elakatothrix genevensis & $0.17 \pm 0.08$ & - & $0.11 \pm 0.02$ & - & 0.6 \\
\hline Micractinium pusillum & $0.03 \pm 0.17$ & + & $0.29 \pm 0.04$ & - & 9.7 \\
\hline Monoraphidium contortum & $0.11 \pm 0.11$ & - & $0.14 \pm 0.10$ & - & 1.3 \\
\hline
\end{tabular}



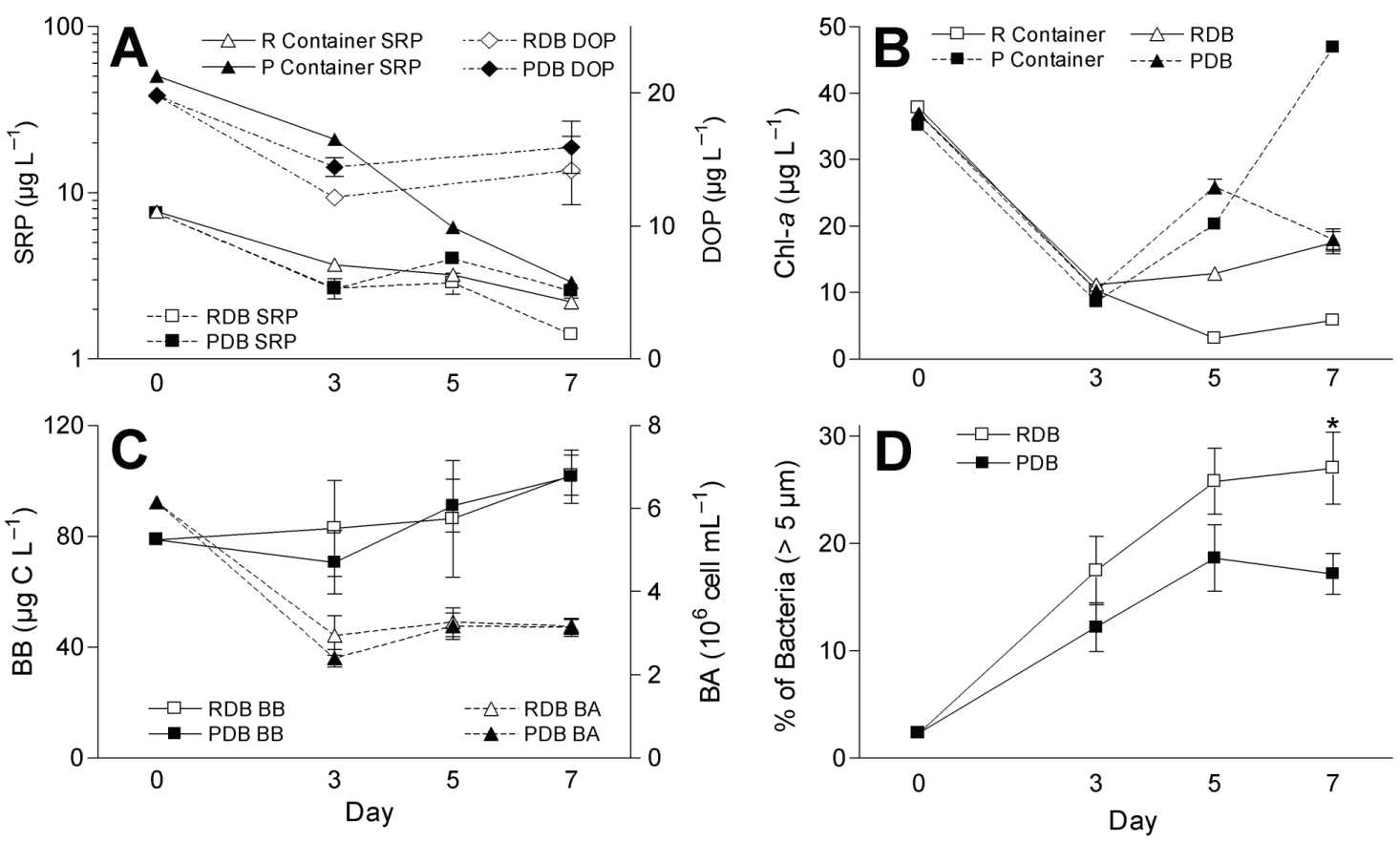

Fig. 3. Selected parameters measured in RDB (open symbols) and PDB (solid symbols) or in containers during the in situ experiment: A: Soluble reactive phosphorus (SRP, left, note logarithmic scale) and dissolved organic phosphorus (DOP, right scale) concentrations. B: Chlorophyll- $a$ concentration (chl-a). C: Bacterial biomass (BB, left scale) and abundance (BA, right scale) in

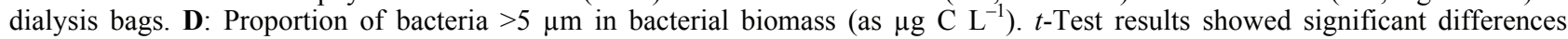
between RDB and PDB at day 7, probability level: ${ }^{*}, P<0.05$. All measurements in the dialysis bags were means of triplicates, error bars show standard error.

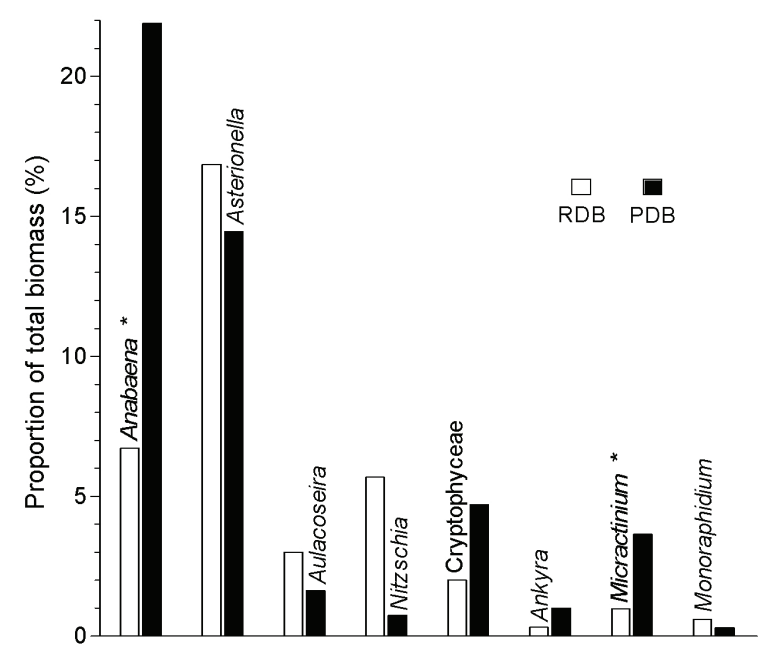

Fig. 4. The most abundant phytoplankton species during the in situ experiment: comparison of their proportions in the total phytoplankton biomass in non-enriched (RDB) and enriched (PDB) dialysis bags at day 7. Bars represent means of triplicates; *: significantly different values $(t$-Test, $P<0.05)$.

Cyanobacteria, namely Anabaena planctonica, initially formed $<1 \%$ of total biomass $\left(0.1 \mathrm{mg} \mathrm{L}^{-1}\right)$; by the end of the study, A. planctonica was more successful in PDB, where formed $22 \%$ of total biomass $\left(1.8 \mathrm{mg} \mathrm{L}^{-1}\right)$, compared to $6.7 \%$ in RDB $\left(0.28 \mathrm{mg} \mathrm{L}^{-1}\right.$; $t$-Test, $P=$ 0.023 ; Fig. 4). The difference in Cyanobacteria biomass between RDB and PDB was significant by day 7 ( $t$-Test, $P=0.023)$. Diatoms Asterionella formosa, Aulacoseira italica and Nitzschia crotonensis formed initially less than $5 \%$ of total biomass (Fig. 2A). All three species were relatively more successful in the RDB treatment by day $7(17 \%, 3 \%$, and $8.5 \%$ of total biomass, respectively); however, the differences were nonsignificant (Fig. 4). Therefore, diatoms were the second most abundant group in RDB after flagellates at the end of the experiment, while cyanobacteria, chlorophytes and 
flagellates were more abundant in the PDB samples (Fig. 2A). Chlorophyceae had the largest species diversity (20 taxa), although their biomass was not high during the whole experiment (initial $0.32 \mathrm{mg} \mathrm{L}^{-1}$; final 0.36 $\mathrm{mg} \mathrm{L}^{-1}$ in RDB and $1.08 \mathrm{mg} \mathrm{L}^{-1}$ in PDB). Ankyra ancora, Micractinium pusillum, and Monoraphidium contortum were the most abundant green algae in both treatments by day 7 , while the first two reached higher biomass in PDB (Fig. 4). The difference in biomass was significant only for $M$. pusillum ( $t$-Test, $P=0.045$ ). Bacterial biomass grew very similarly in both RDB and PDB; it increased from an initial $79 \mu \mathrm{g} \mathrm{C} \mathrm{L}^{-1}$ to a final

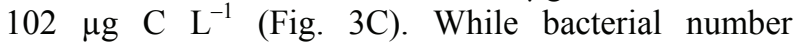
decreased twice during the experiment (Fig. 3C), the proportion of large bacteria $(>5 \mu \mathrm{m})$ increased from $2.3 \%$ to $27 \%$ in RDB and to $17 \%$ in PDB (Fig. $3 \mathrm{D}$ ).

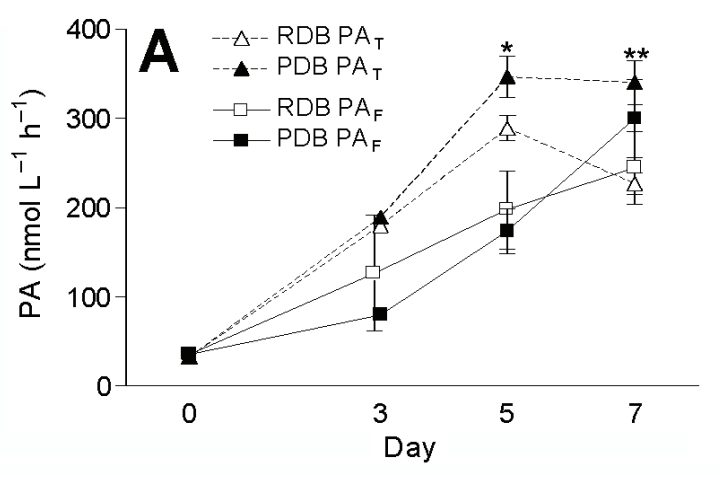

than in RDB by day 5 , while the opposite was the case for $\mathrm{PA}_{\mathrm{F}}$. No significant differences were found between triplicate means of $\mathrm{PA}_{\mathrm{F}}$ determined from $\mathrm{RDB}$ and $\mathrm{PDB}$ (Fig. 5A). The $\mathrm{PA}_{\mathrm{T}}$ of $\mathrm{PDB}$ significantly differed from that of RDB on days 5 and $7(P=0.0498$ and 0.007 , respectively). TP levels were correlated significantly with both $\mathrm{PA}_{\mathrm{T}}(r=0.857, P=0.014)$ and $\mathrm{PA}_{\mathrm{F}}(r=$ $0.964, P=0.001$ ), on the other hand, DOP was not significantly linked to either $\mathrm{PA}_{\mathrm{T}}$ or $\mathrm{PA}_{\mathrm{F}}$.

Table 1 summarises phosphatase activity for 38 phytoplankton species/taxa determined during the enrichment experiment. The ELFA labelling was rare among the phytoplankton, with only several cells of particular populations (except for Ankyra ancora) being found on each inspected filter (i.e., in $4 \mathrm{~mL}$ of water sample). At the beginning, Anabaena planctonica and

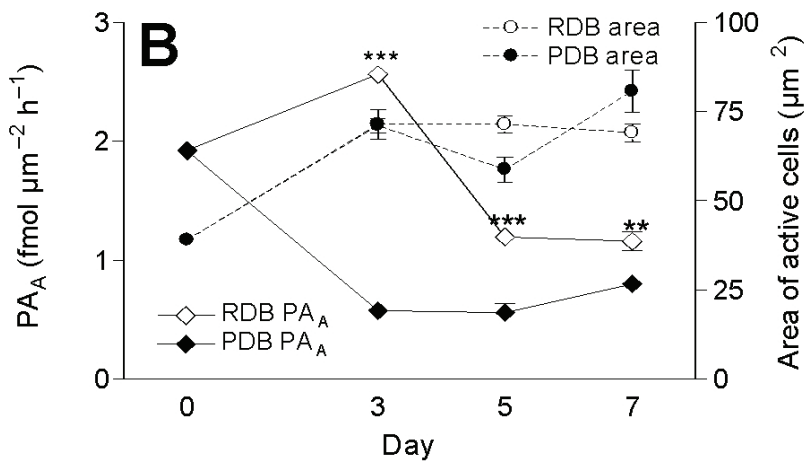

Fig. 5. Phosphatase activity measured in RDB (open symbols) and PDB (solid symbols) during the in situ experiment. A: Extracellular phosphatase activities $\mathrm{PA}_{\mathrm{T}}$, measured with the MUF assay, and $\mathrm{PA}_{\mathrm{F}}$, measured with the ELF assay. $t$-Test found significant differences between $\mathrm{PA}_{\mathrm{T}}$ in $\mathrm{RDB}$ and $\mathrm{PDB}$ treatments at days 5 and 7 , probability levels: ${ }^{*}, P<0.05 ; * *, P<0.01$. B: Extracellular phosphatase activity of Ankyra ancora population $\left(\mathrm{PA}_{\mathrm{A}}\right.$, left scale) and mean projection area of active cells (right scale). $t$-Test found significant differences between $\mathrm{PA}_{\mathrm{A}}$ in RDB and PDB treatments at days 3,5 , and 7 , probability levels: $* *, P$ $<0.01$; ***, $P<0.001$. All values are means of triplicates, error bars show standard error.

Rotifers formed significant part of the enclosed plankton. The most abundant taxa were Polyarthra spp., Synchaeta spp., Keratella cochlearis, and Trichocerca cylindrica (Fig. 2B). Initially, 8,000 individuals $\mathrm{L}^{-1}$ were in the dialysis bags. Synchaeta populations grew by more than six times by day 3 in both RDB and PDB treatments $\left(17,300\right.$ and 21,000 individuals $\mathrm{L}^{-1}$, respectively), further followed by their rapid decline (Fig. 2B). Other rotifer species continued growing; more rotifers were finally in $\operatorname{RDB}\left(21,000\right.$ individuals $\left.\mathrm{L}^{-1}\right)$ than in the enriched PDB (14,000 individuals $\left.\mathrm{L}^{-1}\right)$. Total rotifer numbers in RDB and PDB were not significantly different at day 7 ( $t$-Test, $P=0.078$ ), only $T$. cylindrica numbers differed significantly ( $t$-Test, $P=0.011$ ).

\subsection{Extracellular phosphatase activity}

The initial $\mathrm{PA}_{\mathrm{T}}$ measured with the MUF assay and $\mathrm{PA}_{\mathrm{F}}$ measured with the FLEA assay on filters were comparable (30-38 nmol L ${ }^{-1} \mathrm{~h}^{-1}$; Fig. 5A). Both $\mathrm{PA}_{\mathrm{T}}$ and $\mathrm{PA}_{\mathrm{F}}$ showed a similar pattern of continuous increase until day 5; $\mathrm{PA}_{\mathrm{T}}$ then decreased in both variants, the decrease being greater in $\mathrm{RDB}$. $\mathrm{PA}_{\mathrm{T}}$ was higher in $\mathrm{PDB}$
Micractinium pusillum were ELFA-labelled and were relatively abundant compared to the other labelled species. Populations of A. planctonica were partly and rarely ELFA-labelled both in RDB and PDB. Micractinium pusillum cells were sometimes ELFAlabelled in RDB only. Phosphatase-positive cells were observed among a number of chlorophytes (A. ancora, Crucigenia apiculata, Gonium sociale, Oocystis parva, etc.). The cells of $A$. ancora were labelled intensively and often; therefore it was possible to calculate $\mathrm{PA}_{\mathrm{A}}$ (Fig. 5B). The highest $\mathrm{PA}_{\mathrm{A}}$ was at day 3 in $\mathrm{RDB}(2.56$ fmol $\mu \mathrm{m}^{-2} \mathrm{~h}^{-1}$ ), which then declined by more than half

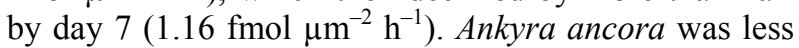
often ELFA-labelled in $\mathrm{PDB}$, with the $\mathrm{PA}_{\mathrm{A}}$ decreasing by day $5\left(0.56\right.$ fmol $\left.\mu \mathrm{m}^{-2} \mathrm{~h}^{-1}\right)$; however, it slightly increased afterwards $\left(0.8 \mathrm{fmol} \mu \mathrm{m}^{-2} \mathrm{~h}^{-1}\right)$. The $\mathrm{PA}_{\mathrm{A}}$ in RDB and PDB differed significantly on days 3,5 and 7 $(P=0.0005,0.001$ and 0.009 , respectively). The area of ELFA-labelled cells of $A$. ancora almost doubled in both treatments by day 3 and then remained stable (Fig. 5B). Cryptomonads, the most abundant phytoplankton group at the beginning of the study, were never ELFA- 
labelled. Among the diatoms, Asterionella formosa, Aulacoseira italica and Fragilaria crotonensis were ELFA-labelled in RDB only. Finally, there were 17 ELFA-labelled taxa in RDB, while 11 taxa were labelled in PDB. The difference between initial and final numbers of ELFA-labelled taxa was significant in RDB $\left(\chi^{2}=7.54, P=0.003\right)$ but nonsignificant in PDB $\left(\chi^{2}=1.89, P=0.08\right)$. The difference in the number of ELFA-labelled taxa between RDB and PDB was nonsignificant $\left(\chi^{2}=2.04, P=0.077\right)$

\subsection{Specific growth rates}

Specific growth rates of several phytoplankton species were significantly greater $(P=0.029)$ in PDB $\left(\right.$ median $=0.32$ day $^{-1}$ ) than in RDB (median $=0.11$ day $^{-1}$; Tab. 2). In all but one case (Elakatothrix genevensis), the growth rates were higher in enriched PDB than in RDB; however, the differences within a particular species population were all nonsignificant. Species that grew faster in PDB bags were either not producing phosphatases or the phosphatase activity was lower, as documented for Ankyra ancora (Fig. 5B). This was not proven for Anabaena planctonica since it was not possible to measure cell-specific phosphatase activity on its dense filaments.

\section{DISCUSSION}

Different ability to produce cell-surface-bound phosphatases could have fundamental implication for the adaptive biology of phytoplankton species. We investigated to what extent the production of extracellular phosphatases favoured single species in natural environment and, moreover, if this ability could help the species to proliferate amongst natural phytoplankton assemblage. Further, we compared the species-specific growth rates in two different bioavailable phosphate concentrations.

\subsection{Dynamics of phytoplankton community}

In the beginning of the experiment, similar trends were recorded in both the enriched PDB and nonenriched RDB samples: a rapid decline in cryptomonads and increases in flagellates and cyanobacteria during the first three days. Interestingly, the chl- $a$ concentration in the reservoir water (i.e., in the open R-container) decreased similarly as in the dialysis bags, which could imply uniform development of the phytoplankton assemblage in the reservoir as well as in the enclosures. On the other hand, enclosures, even if being permeable dialysis bags, most probably generated different conditions inside as compared to the external environment within next few days. Still, our aim was to compare the development of the same initial phytoplankton assemblage split and exposed to different $P_{i}$ concentrations, but under comparable environmental conditions. Extra $\mathrm{P}_{\mathrm{i}}$ was added into the P-container and not directly into the dialysis bags, to study plankton response to a grad- ual input rather than to a single pulse of P. However, exchange through the permeable membrane was slow and bacteria and phytoplankton possibly took up majority of $\mathrm{P}_{\mathrm{i}}$ already in the container and the microbial community inside the PDB utilised only a limited amount. On the other hand, it is very likely that some additional $P_{i}$ could gradually enter the PDB due to accelerated $\mathrm{P}$ regeneration by the microbial community in the container. Thus, the plankton community in PDB could pump inward the $\mathrm{P}_{\mathrm{i}}$ available from the P-container. As a result, phytoplankton biomass increased more in the PDB samples and also less species were phosphatase-positive.

Cryptophyceae were dominant at the beginning of the experiment. Cryptomonads occasionally form the majority of phytoplankton biomass during the clearwater phase in the Římov Reservoir (Komárková et al. 2003; Štrojsová et al. 2003). Regular sampling in July 2004 showed that cryptomonads formed a peak in the reservoir, which lasted even during the experiment (data of the Institute of Hydrobiology, České Budějovice). The rapid decrease in the abundant cryptomonad population could not be explained only by, e.g., rotifer grazing. Lethal enclosure effect on cryptomonads has been observed in several Czech reservoirs (P. Znachor, personal communication), which could be the main reason of the cryptomonad decline in our experiment.

Cyanobacteria, specifically Anabaena planctonica, formed a higher proportion of the total biomass in enriched PDB than in RDB. The $\mathrm{N}_{2}$-fixing $A$. planctonica population might be favoured when $\mathrm{P}_{\mathrm{i}}$ is amended and the N:P ratio is low (Levine \& Schindler 1999). Although the N:P ratio was not determined in our study, the P-enrichment might shift the ratio to lower level, which might play a role in the success of $A$. planctonica. Relatively low cyanobacterial biomass in RDB compared to higher biomass of chlorophytes and diatoms might support this explanation. Large diatoms (Asterionella formosa, Aulacoseira italica, and Nitzschia acicularis) increased in abundance in both RDB and PDB. However, diatoms formed a higher proportion of the total biomass in RDB, especially $A$. formosa, which is tolerant of lower irradiance (Reynolds 1997), e.g., inside the container. Thingstad et al. (2005) suggested that the success of diatoms could be based on their "Winnie-the-Pooh" strategy: a high nutrient affinity relative to a large cell size that allows escape from predation. In this experiment, large zooplankton were removed and therefore diatoms were probably even more favoured. Diatoms were relatively less successful in PDB, probably because of stronger competition from the abundant cyanobacterium $A$. planctonica.

Planktonic rotifers in the Rímov Reservoir have never reached such a high abundance (cf. Devetter \& Sed'a 2003) as in the dialysis bags. Rotifers probably profited from their ability of fast adaptation to varying conditions (Herzig 1987) and high rate of reproduction 
(Cajander 1983). Moreover, ample food supplies along with no predation pressure by fish and large zooplankton favoured their increase. Increase in rotifer abundance (except for Synchaeta by day 7) in all dialysis bags implied rather tolerance to the enclosures as was previously observed by, e.g., Gonzáles (2000). Rotifers probably controlled the phytoplankton assemblage, because - especially in dialysis bags with higher rotifer numbers (PDB at day 3 and RDB at days 5 and 7) phytoplankton biomass was lower. Despite this relationship was not significant, abundant rotifer populations most probably intensified phytoplankton biomass turnover and nutrient regeneration in the dialysis bags.

\subsection{Phosphatase activity}

The current concept of extracellular phosphatase activity regulation predicts an inverse relationship between phosphatase activity and phytoplankton growth rate (Healey \& Hendzel 1979; Olsen et al. 1983) or cellular P (Gage \& Gorham 1985). Low phosphatase activity is assumed to be a consequence of the repression of phosphatase synthesis caused by high cellular $\mathrm{P}$ content (e.g., Chróst 1991) and high cellular P content leads (if microbial growth is P-limited) to a high growth rate (Droop 1973). Conversely, high phosphatase activity should occur at low cellular P content, which also implies a low growth rate (Vadstein et al. 1988).

Based on the above assumptions, extracellular phosphatase activity has been proposed as an indicator of Plimited phytoplankton; for such indication, bulk phosphatase activity (e.g., $\mathrm{PA}_{\mathrm{T}}$ ) used to be normalised per phytoplankton biomass (e.g., Healey \& Hendzel 1980; Gage \& Gorham 1985; Chróst 1991). Superficial interpretation of the above, however, may lead to an incorrect assumption that the whole P-limited phytoplankton react this way and plankton ecologists should be aware of this oversimplification. Recent FLEA studies have suggested very diverse species-specific reactions in the same ambient $\mathrm{P}_{\mathrm{i}}$ concentrations (Rengefors et al. 2003; Cao et al. 2005; Štrojsová et al. 2003, 2005; Dyhrman \& Ruttenberg 2006). Moreover, the activity of cell-surface-bound phosphatases, produced by particular algal population, could fluctuate on the time scale of several hours (Štrojsová \& Vrba 2008). Thus, phytoplankton could cause explicit short-term variation in the bulk activity $\left(\mathrm{PA}_{\mathrm{T}}\right)$. Therefore, we would like to warn that $\mathrm{PA}_{\mathrm{T}}$ alone could be misleadingly interpreted as an indicator of $\mathrm{P}$ deficiency/sufficiency. We suggest more frequent sampling for phosphatase analysis or to use the FLEA assay to evaluate an actual proportion of phosphatase-positive phytoplankton (or bacterioplankton) species.

Initial $\mathrm{PA}_{\mathrm{F}}$ and $\mathrm{PA}_{\mathrm{T}}$ were low, as is usual during spring and/or early summer in the Rímov Reservoir (Vrba et al. 1993; Štrojsová et al. 2003). $\mathrm{PA}_{\mathrm{F}}$ was higher in RDB by day 3, as was expected; however, the difference was nonsignificant. $\mathrm{PA}_{\mathrm{T}}$ was very similar in both variants. $\mathrm{PA}_{\mathrm{F}}$ and $\mathrm{PA}_{\mathrm{T}}$ increased in both treatments by day 7 , however, significantly more in PDB. This could be explained by the equally low SRP in all dialysis bags starting at day 3, whereas phytoplankton biomass was higher in PDB. The more abundant phytoplankton in PDB produced less phosphatase per biomass unit. No direct relationships between $\mathrm{PA}_{\mathrm{T}}, \mathrm{PA}_{\mathrm{F}}$ and DOP or SRP were found, suggesting that the rate of enzymatic hydrolysis did not depend on ambient SRP concentration or that $\mathrm{P}_{\mathrm{i}}$ concentration was sufficient for the majority of phytoplankton, as implied by the observed C:P ratios. Therefore, the internal microbial $\mathrm{P}$ pool probably regulated the production of phosphatases (Caruso et al. 2005).

Chrysophyceae and Dinophyceae were not phosphatase-positive except in one case (Gymnodinium uberrimum). That could be caused by their different sensitivity to $\mathrm{P}$ availability and likewise their mixotrophic capacities (Reynolds 1997). Three diatom species (Asterionella formosa, Aulacoseira italica, and Fragilaria crotonensis) were phosphatase-positive in RDB only and grew slower than in enriched PDB, where P supply strongly supported their development (Buzzi 2002).

Ankyra ancora reduced its phosphatase activity in enriched PDB after $\mathrm{P}_{\mathrm{i}}$ addition. When this extra ambient $\mathrm{P}_{\mathrm{i}}$ was exhausted, the $\mathrm{PA}_{\mathrm{A}}$ slightly increased again. Such an effect shows the flexibility and adaptability of $A$. ancora. A comparable influence of $\mathrm{P}$ concentration on phosphatase activity in populations of $A$. ancora, two cyanobacteria Microcystis aeruginosa and Aphanizomenon flos-aquae, and the diatom Fragilaria crotonensis was previously found in Rímov Reservoir (Štrojsová et al. 2005). Interestingly, the phosphatase-positive cells of $A$. ancora increased their size in both treatments equally, although the population in PDB grew much faster and the $\mathrm{PA}_{\mathrm{A}}$ was lower. We hypothesize that brand new daughter cells had sufficient phosphorus reserves and therefore did not employ extracellular phosphatases until they matured and needed extra bioavailable phosphorus to support their metabolism before cell division.

Lower $\mathrm{PA}_{\mathrm{F}}$, compared to $\mathrm{PA}_{\mathrm{T}}$, was already found in our earlier study (Štrojsová et al. 2005). This phenomenon can be caused by (i) different ELFP and MUFP hydrolysis rates and (ii) the ELFP concentration (20 $\mu \mathrm{mol} \mathrm{L} \mathrm{L}^{-1}$ ) used. The ELFP hydrolysis rate only slightly exceeded $50 \%$ of the maximum velocity at this concentration (Nedoma et al. 2003, 2007). The chosen ELFP concentration was a compromise between assay sensitivity and affordability. A lag phase before an increase in ELFA fluorescence occurred (Nedoma et al. 2003). Thus, some amount of ELFA molecules could pass through the filter when not precipitating. Nevertheless, differences in the A. ancora cell-associated ELFA fluorescence measured in this study reflect actual differences in $\mathrm{PA}_{\mathrm{A}}$. 
$P_{i}$ addition caused increased phytoplankton growth and partial depression of phosphatase production. In the non-enriched environment, phytoplankton species produced extracellular phosphatases more often and also their specific growth rates were lower; growth was constrained by lower $\mathrm{P}_{\mathrm{i}}$ supply and probably the extra energy invested in synthesis of these enzymes.

The difference in extracellular phosphatase production was shown within different algal groups, for instance, Cyanobacteria or Chlorophyceae were phosphatase-positive more often than Chrysophyceae or Cryptophyceae in three consecutive years (Štrojsová et al. 2003). Contrasting growth strategies (survivalists vs bloomers) and/or distinct resource co-limitation of the phytoplankton species (Arrigo 2005), and also physiological history of individual cell, internal $\mathrm{P}$ pool, and/or the need of extra $\mathrm{P}_{\mathrm{i}}$ (e.g., before cell division) may reflect the heterogeneity in phosphatase production. Nevertheless, extracellular phosphatases advantage their algal or cyanobacterial producer in competition for resources in a situation when internal reserves or ambient $P_{i}$ is scarce, because only the cells that can produce these enzymes will be able to cleave $\mathrm{P}_{i}$ from DOP, and therefore survive or accomplish more cell divisions, even though their growth rates may be suboptimal. Based on our data, we assume that the threshold concentration of $\mathrm{P}_{\mathrm{i}}$ under which cell activates the production of the enzyme is distinct among phytoplankton species and would be the most interesting topic for future laboratory studies. Here we have shown that, under conditions where $\mathrm{P}_{\mathrm{i}}$ was present in lower concentrations, the production of phosphatases was enhanced, but these active species did not proliferate amongst phytoplankton assemblage. The regulation of the cell-surface-bound enzyme activity and the proportion to which the enzyme is present in different phytoplankton species populations needs particular attention and further investigation.

\section{ACKNOWLEDGEMENTS}

This project was supported by the Grant Agency of ASCR (projects No. A 6017202 and A600170602) and partly by the Czech Ministry of Education, Youth and Sports (projects ME 617 and MSM 6007665801), and the National Basic Research Program of China (project No. 2002CB412300). We acknowledge laboratory assistance of R. Malá, M. Štojdlová, V. Hejzlarová, J. Kroupová, and K. Murtinger. K.R. Edwards revised the English text.

\section{REFERENCES}

Arrigo, K.R. 2005. Marine microorganisms and global nutrient cycles. Nature, 437: 349-355.

Arvola, L., P. Kankaala, T. Tulonen \& A. Ojala. 1996. Effects of phosphorus and allochthonous humic matter enrichment on the metabolic processes and community structure of plankton in a boreal lake (Lake Pääjärvi). Can. J. Fish. Aquat. Sci., 53: 1646-1662.

Buzzi, F. 2002. Phytoplankton assemblages in two sub-basins of Lake Como. J. Limnol., 61: 117-128.
Cajander, V.R. 1983. Production of planktonic Rotatoria in Ormajärvi, an eutrophicated lake in southern Finland. Hydrobiologia, 104: 329-333.

Cao, X., A. Strojsová, P. Znachor, E. Zapomělová, G. Liu, J. Vrba \& Y. Zhou. 2005. Detection of extracellular phosphatases in natural spring phytoplankton of a shallow eutrophic lake (Donghu, China). Eur. J. Phycol., 40: 251258 .

Caruso, G., L. Monticelli, F. Azzaro, M. Azzaro, F. Decembrini, R. La Ferla, M. Leonardi \& R. Zaccone. 2005. Dynamics of extracellular enzymatic activities in a shallow Mediterranean ecosystem (Tindari ponds, Sicily). Mar. Freshwater Res., 56: 173-188.

Christian, J.R. \& D.M. Karl. 1995. Measuring bacterial ectoenzyme activities in marine waters using mercuric chloride as a preservative and a control. Mar. Ecol. Prog. Ser., 123: 217-224

Chróst, R.J. 1991. Environmental control of the synthesis and activity of aquatic microbial ectoenzymes. In: Chróst, R.J. (Ed.), Microbial Enzymes in Aquatic Environments. Springer, New York: 29-59.

Cottingham, K., S. Carpenter \& A.S. Amand. 1998. Responses of epilimnetic phytoplankton to experimental nutrient enrichment in three small seepage lakes. J. Plankton Res., 20: 1889-1914.

Devetter, M. \& J. Sed'a. 2003. Rotifer fecundity in relation to components of microbial food web in a eutrophic reservoir. Hydrobiologia, 504: 167-175.

Dignum, M., H.L. Hoogveld, H.C.P. Matthijs, H.J. Laanbroek \& R. Pel. 2004. Detecting the phosphate status of phytoplankton by enzyme-labelled fluorescence and flow cytometry. FEMS Microbiol. Ecol., 48: 29-38.

Droop, M.R. 1973. Some thoughts on nutrient limitation in algae. J. Phycol., 9: 264-272.

Dyhrman, S.T., E.A. Webb, D.M. Anderson, J.W. Moffett \& J.B. Waterbury. 2002. Cell specific detection of phosphate stress in Trichodesmium from the Western North Atlantic. Limnol. Oceanogr., 47: 1832-1836.

Dyhrman, S.T. \& B. Palenik. 1999. Phosphate stress in cultures and field populations of the dinoflagellate Prorocentrum minimum detected by a single-cell alkaline phosphatase assay. Appl. Environ. Microb., 65: 3205-3212.

Dyhrman, S.T. \& K.C. Ruttenberg. 2006. Presence and regulation of alkaline phosphatase activity in eukaryotic phytoplankton from the coastal ocean: implications for dissolved organic phosphorus remineralization. Limnol. Oceanogr., 51: 1382-1390.

Gage, M.A. \& E. Gorham. 1985. Alkaline phosphatase activity and cellular phosphorus as an index of the phosphorus status of phytoplankton in Minnesota lakes. Freshwat. Biol., 15: 227-233.

Gonzáles, E.J. 2000. Nutrient enrichment and zooplankton effects on the phytoplankton community in microcosms from Al Andino reservoir (Venezuela). Hydrobiologia, 434: 81-96.

Gonzáles-Gil, S., B. Keafer, R.V.M. Jovine, A. Aquilera, S. Lu \& D.M. Anderson. 1998. Detection and quantification of alkaline phosphatase in single cells of phosphorusstarved marine phytoplankton. Mar. Ecol. Prog. Ser., 164: 21-35.

Healey, F.P. \& L.L. Hendzel. 1979. Indicators of phosphorus and nitrogen deficiency in five algal cultures. J. Fish. Res. Board Can., 36: 1364-1369.

Healey, F.P. \& L.L. Hendzel. 1980. Physiological indicators of nutrient deficiency in lake phytoplankton. Can. J. Fish. Aquat. Sci., 37: 442-453.

Hecky, R.E. \& P. Kilham. 1988. Nutrient limitation of phytoplankton in freshwater and marine environments: a review of recent evidences of the effects of enrichment. Limnol. Oceanogr., 33: 796-822. 
Herzig, A. 1987. The analysis of planktonic rotifer populations: A plea for long term investigations. Hydrobiologia, 147: $163-180$

Hoppe, H.G. 1983. Significance of exoenzymatic activities in the ecology of brackish water: measurements by means of methylumbelliferyl substrates. Mar. Ecol. Prog. Ser., 11: 299-308.

Huang, Z., E. Terpetschnig, W. You \& R.P. Haugland. 1992. 2-(2'-phosphoryloxyphenyl)-4(3H)-quinazolinone derivates as fluorogenic precipitating substrates of phosphatases. Anal. Biochem., 207: 32-39.

Jansson, M., H. Olsson \& K. Pettersson. 1988. Phosphatases; origin, characteristic and function in lakes. Hydrobiologia, 170: $157-175$

Kobayashi, T. \& A.G. Church. 2003. Role of nutrients and zooplankton grazing on phytoplankton growth in a temperate reservoir in New South Wales, Australia. Mar. Freshwater Res., 54: 609-618.

Komárková, J., O. Komárek \& J. Hejzlar. 2003. Evaluation of the long term monitoring of phytoplankton assemblages in a canyon-shape reservoir using multivariate statistical methods. Hydrobiologia, 504: 143-157.

Kopáček, J. \& J. Hejzlar. 1993. Semi-micro determination of total phosphorus in fresh waters with perchloric acid digestion. Int. J. Environ. An. Ch., 53: 173-183.

Kuenzler, E. \& J. Perras. 1965. Phosphatases in marine algae. Biol. Bull., 128: 271-284.

Levine, S.N. \& D.W. Schindler. 1999. Influence of nitrogen and phosphorus supply ratios and physicochemical conditions on cyanobacteria and phytoplankton species composition in the Experimental Lakes Area, Canada. Can. J. Fish. Aquatic Sci., 56: 451-466.

Lomas, W.M., A. Swain, R. Sgelton \& J.W. Ammerman. 2004. Taxonomic variability of phosphorus stress in Sargasso Sea phytoplankton. Limnol. Oceanogr., 49: 309315.

Murphy, J. \& J.P. Riley. 1962. A modified single-solution method for the determination of phosphate in natural waters. Analyt. Chim. Acta, 27: 31-36.

Nedoma, J., A. Štrojsová, J. Vrba, J. Komárková \& K. Šimek. 2003. Extracellular phosphatase activity of natural plankton studied with ELF97 phosphate: fluorescence quantification and labelling kinetics. Environ. Microbiol., 5: 462472.

Nedoma, J., F. Van Wambeke, A. Štrojsová, M. Štrojsová \& S. Duhamel. 2007. Affinity of extracellular phosphatases for ELF97 phosphate in aquatic environments. Mar. Freshwater Res., 58: 454-460.

Norland, S. 1993. The relationship between biomass and volume of bacteria. In: Kemp, P.F., B.F. Sherr, E.B. Sherr \& J.J. Cole (Eds), Handbook of Methods in Aquatic Microbial Ecology, Lewis Publishers, Boca Raton: 303-308.

Ojala, A., S. Kokkonen \& T. Kairesalo. 2003. The role of phosphorus in growth of phytoplankton in Lake Vesijärvi, southern Finland - a multitechnique approach. Aquat. Sci., 65: 287-296.

Olsen, Y., G. Knutsen \& T. Lien. 1983. Characteristic of phosphorus limitation in Chlamydomonas reinhardtii (Chlorophyceae) and its palmelloids. J. Phycol., 19: 313319.

Porter, K.G. \& Y.S. Feig. 1980. The use of DAPI for identifying and counting aquatic microflora. Limnol. Oceanogr., 25: 943-948.

Received: July 2008

Accepted: August 2008
Psenner, R. 1993. Determination of size and morphology of aquatic bacteria by automated image analysis. In: Kemp, P.F., B.F. Sherr, E.B. Sherr \& J.J. Cole. (Eds), Handbook of Methods in Aquatic Microbial Ecology, Lewis Publishers, Boca Raton: 339-345.

Rengefors, K., K.C. Ruttenberg, C.L. Haupert, C.D. Taylor, B.L. Howes \& D.M. Anderson. 2003. Experimental investigation of taxon-specific response of alkaline phosphatase activity in natural freshwater phytoplankton. Limnol. Oceanogr., 48: 1167-1175.

Reynolds, C.S. 1997. Vegetation processes in the pelagic: a model for ecosystem theory. Ecology Institute, Germany: $371 \mathrm{pp}$.

Siuda, W \& R.J. Chróst. 1987. The relationship between alkaline phosphatase activity (APA) and phosphate availability for phytoplankton and bacteria in eutrophic lakes. Acta Microbiol. Polon., 36: 247-257.

Štrojsová, A. \& S.T. Dyhrman. 2008. Cell-specific $\beta$-N-acetylglucosaminidase activity in cultures and field populations of eukaryotic marine phytoplankton. FEMS Microb. Ecol., 64: 351-361.

Štrojsová, M. \& J. Vrba. 2005. Direct detection of digestive enzymes in planktonic rotifers using enzyme labelled fluorescence (ELF). Mar. Freshwater Res., 56: 189-195.

Štrojsová, A. \& J. Vrba. 2006. Phytoplankton extracellular phosphatases: Investigation using the ELF (Enzyme Labelled Fluorescence) technique. Pol. J. Ecol., 54: 715723.

Štrojsová, M. \& J. Vrba. 2007. Rotifer digestive enzymes: direct detection using the ELF technique. Hydrobiologia, 593: 159-165.

Štrojsová, A. \& J. Vrba. 2008. Short-term variation in extracellular phosphatase activity: possible limitations for diagnosis of nutrient status in particular algal populations. Aquat. Ecol., DOI 10.1007/s10452-007-9154-7.

Štrojsová, A., J. Vrba, J. Nedoma, J. Komárková \& P. Znachor. 2003. Seasonal study on expression of extracellular phosphatases in the phytoplankton of an eutrophic reservoir. Eur. J. Phycol., 38: 295-306.

Štrojsová, A., J. Vrba, J. Nedoma \& K. Šimek. 2005. Extracellular phosphatase activity of freshwater phytoplankton exposed to different in situ phosphorus concentrations. Mar. Freshwater Res., 56: 417-424.

Thingstad, T.F., L. Øvreas, J.K. Egge, T. Løvdal \& M. Heldal. 2005. Use of non-limiting substrates to increase size; a generic strategy to simultaneously optimize uptake and minimize predation in pelagic osmotrophs? Ecol. Lett., 8: 675-682.

Vadstein, O., A. Jensen, Y. Olsen \& H. Reinertsen. 1988. Growth and phosphorus status of limnetic phytoplankton and bacteria. Limnol. Oceanogr., 33: 489-503.

Vrba, J., J. Komárková \& V. Vyhnálek. 1993. Enhanced activity of alkaline phosphatases - phytoplankton response to epilimnetic phosphorus depletion. Water Sci. Technol., 28: $15-24$.

Vyhnálek, V. 1994. Determination of chlorophyll- $a$ in fresh waters using the whole-water technique. J. Plankton Res., 16: $795-808$.

Wetzel, R.G. 1981. Longterm dissolved and particulate alkaline phosphatase activity in a hardwater lake in relation to lake stability and phosphorus enrichments. Verh. int. Ver. Limnol., 21: 369-381. 